\title{
Characteristics of the Coagulate Obtained During the Process of Model Wastewater Treatment
}

\author{
Julija Brovkina ${ }^{1}$, Galija Shulga ${ }^{1}$, Jurijs Ozolins ${ }^{2}$, Zilgma Irbe ${ }^{2}$, Maris Turks $^{2}$, Vitalijs Rjabovs ${ }^{2}$ \\ 1 - Latvian State Institute of Wood Chemistry \\ Address: 27 Dzerbenes str., Riga, LV-1006, Latvia, \\ 2 - Riga Technical University, Faculty Of Material Science And Applied Chemistry \\ Address: 14/24 Azenes Str., Riga, LV-1048, Latvia.
}

\begin{abstract}
In the process of wastewater treatment by coagulation a large amount of sediment is being produced, which is the main drawback of this method. Therefore, the development of utilization or recirculation technology of the waste obtained, the research of the obtained by-products should be conducted. Within the scope of this work, the sediment, that is being formed during the coagulation of the model wastewater containing the wood originated pollutants, was studied. Using the aluminium-containing composition coagulant on a base of polyaluminium chloride, coagulates characterized by the low sludge volume index within 30 minutes $\left(89 \mathrm{ml} \mathrm{g}^{-1}\right)$, and the optimal time of sedimentation is 20-30 minutes. The coagulate particles have an average size of $45.8 \mu \mathrm{m}$. The derived coagulate is composed primarily of carbon (27.9\%), oxygen $(49.4 \%)$ and aluminum (10.9\%). Carbon, oxygen and hydrogen belong to an organic part of coagulate - the wood pollutants, which, in turn, has a high content of hemicellulose. It is concluded that the existing hemicellulose in the obtained coagulate is characterized by $O$-acetyl-4-O-methyl-D-glucuron- $\beta$-D-xylan with $\beta$-(1-4)-glucomannose.
\end{abstract}

Keywords - coagulation, model wastewater, coagulate, hemicellulose, lignin-containing substances.

\section{INTRODUCTION}

Latvia is one of the major plywood manufacturers in Eastern Europe. The hydrothermal wood treatment is one of the stages of plywood production, resulting in water pollution by components such as hemicellulose, lignin and wood extractive substances (HLES). The wastewater can cause considerable damage to the receiving waters if discharged untreated.

Several physico-chemical colour removal methods such as rapid sand filtration, membrane processes and adsorption have also been developed [1, 2]. However, the most acceptable technology of wastewater treatment within the framework of enterprise, applied presently, is based on the processes of coagulation. Chemical coagulation is a frequently applied process in primary purification of industrial wastewater. Coagulation is mainly induced by inorganic metal salts, such as aluminium sulphates and chlorides [3]. Research and practical applications have shown that coagulation will lower the pollution load and could generate an adequate water recovery $[4,5]$.

However, it should be noted that the most important drawback of the coagulation method is the large amount of the produced sludge that needs to be eliminated or used as a raw material for other technologies. The sludge produced during the physical-chemical treatment has arisen due to the amount of organic matter and total solids in suspension that have been removed, and the compounds, formed from the coagulant applied. Sewage sludge can be used as a fuel with a high calorific value [6], as a component of soil recovery [7], for the production of building [8] and sorbent materials $[9,10]$.
Based on the above, the goal of the present study was to describe HLES coagulate, which occurs due to the process of model wastewater coagulation by using new Al-composition coagulants.

\section{MATERIALS AND METHODS}

The birch wood sawdust was used for the wood hydrothermal treatment. A hydrolysis was fulfilled in an alkaline water environment, at the water duty of $1 / 50$, the temperature $90{ }^{\circ} \mathrm{C}$ and the duration was about 4 hours. The model wastewater was described by HLES content, $\mathrm{COD}, \mathrm{BOD}_{5}$ and its color $[11,12]$.

In order to find the wood pollutants coagulation pattern and to develop optimal conditions of wastewater treatment technologies, studies of the process of coagulation of model wastewater were completed using the aluminium-containing coagulants. The model wastewater coagulation process was performed using composite coagulant on PAC basis (COMPAC) [13] with dosage $100 \mathrm{mg} \mathrm{L}^{-1}$ at $\mathrm{pH} 6.0$ and a room temperature.

The coagulation tests involved the rapid addition of the coagulant to the model wastewater followed by stirring at $100 \mathrm{rpm}$. After addition of coagulants, the model wastewater was stirred for a period of $1 \mathrm{~min}$ at $200 \mathrm{rpm}$ and then it was followed by a further slow mixing of 2 $\min$ at $40 \mathrm{rpm}$. The formed flocs were allowed to settle for $120 \mathrm{~min}$. In the process of sedimentation the volume with sludge occupying the $100 \mathrm{ml}$ cylinder, was recorded every 30 minutes. The data received contributed in defining the sludge volume index (SVI). The sludge volume index is the volume in milliliters occupied by $1 \mathrm{~g}$ of a suspension after $30 \mathrm{~min}$ of settling. To determine the 
size of the coagulate particles the Laser Particle Sizer ANALYSETTE 22 NanoTec (Fritsch GmbH, Germany) with measuring range of $10 \mathrm{~nm}-1 \mathrm{~mm}$ and Leica MZ 16 A stereomicroscope (Leica Microsystems (Switzerland) Ltd.) were used. The results are represented as a percent of complete sample volume, that is filled with particles with defined diameter and as a percent of mass content of defined particles fraction.

After 120 minutes of sedimentation, the system was filtered through a glass filter with a pore size of less than $16 \mu \mathrm{m}$. The filtered sludge was drained of for 24 hours at $103^{\circ} \mathrm{C}$. The dried coagulates (HLES-Al) were quantatively and qualitatively characterized by scanning electron microscope (SEM) with energy dispersive X-ray analysis (EDX) (Mira/LMU Schottky, Inca Energy 350 Oxford Instruments), Fourier Transform Infrared (FT-IR) and Carbon Nuclear Magnetic Resonance $\left({ }^{13} \mathrm{C}-\mathrm{NMR}\right)$ spectroscopy. For HLES-Al characterization FT-IR spectra was obtained on a FT-IR spectrophotometer (Perkin-Elmer Spectrum One) with $\mathrm{KBr}$ discs containing samples. ${ }^{13} \mathrm{C}-\mathrm{NMR}$ spectra of HLES-Al was recorded on a Bruker $300 \mathrm{MHz}$ spectrometer from $150 \mathrm{mg}$ of sample dissolved in 4\% NaOD (1.0 mL). The NMR spectrum was acquired by applying a $90^{\circ}$ pulse width, a $0.238 \mathrm{~s}$ acquisition time, a $2.0 \mathrm{~s}$ pulse delay, and ${ }^{1} \mathrm{~J}_{\mathrm{C}-\mathrm{H}}$ of $145 \mathrm{~Hz}$. In particular, 24576 scans were used for the acquisition of ${ }^{13} \mathrm{C}$-NMR spectra of coagulate.

\section{RESULTS AND DISCUSSION}

In the coagulation process, the settling speed of the flocs formed is important since it would influence the overall cost and efficiency.

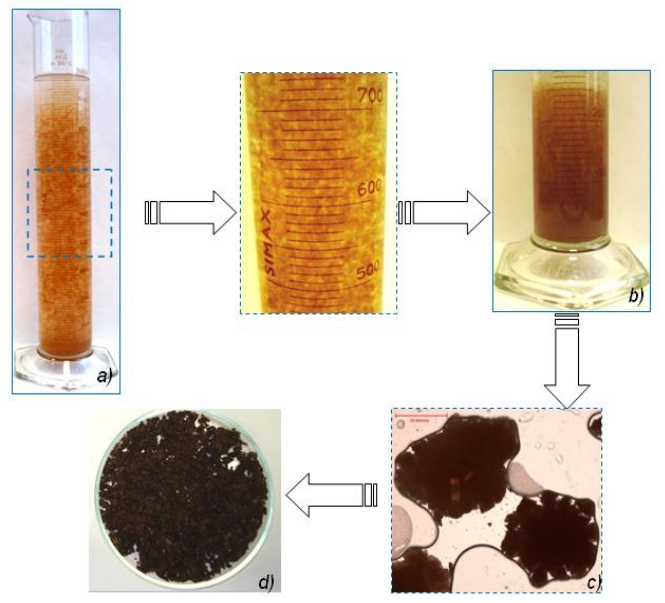

Fig. 1. HLES-Al coagulates formation process: a - beginning of sedimentation, b- coagulates developed, $\mathrm{c}$ - coagulates particles (Leica MZ 16 A stereomicroscope), d - dry coagulate

In order to evaluate this parameter, the settling time was recorded for the flocs formed in order to reach half of the solution's level. COMPAC exhibited excellent settling characteristics with majority of the flocs settled out in the initial 20-30 min of settling. The sludge volume index is $89 \mathrm{ml} \mathrm{g}^{-1}$. A value less than $140 \mathrm{ml} \mathrm{g}^{-1}$ is considered a good settling sludge. Coagulate HLES-Al is characterized by high moisture $-98.2 \%$.
The research of coagulates granulometric composition (Fig. 2) followed by the fact that the coagulate particles' sizes are ranging from 2 to $246 \mu \mathrm{m}$. Analyzing the data obtained, it can be concluded that $53 \%$ of the particles' size is between 40 and $100 \mu \mathrm{m}, 22 \%$ of the particles - 16$40 \mu \mathrm{m}$ and $25 \%$ of the particles have a size of $100 \mu \mathrm{m}$. By contrast, smaller particles $(<16 \mu \mathrm{m})$ is $1 \%$. The average particle size is equal to $45.8 \mathrm{~mm}$.
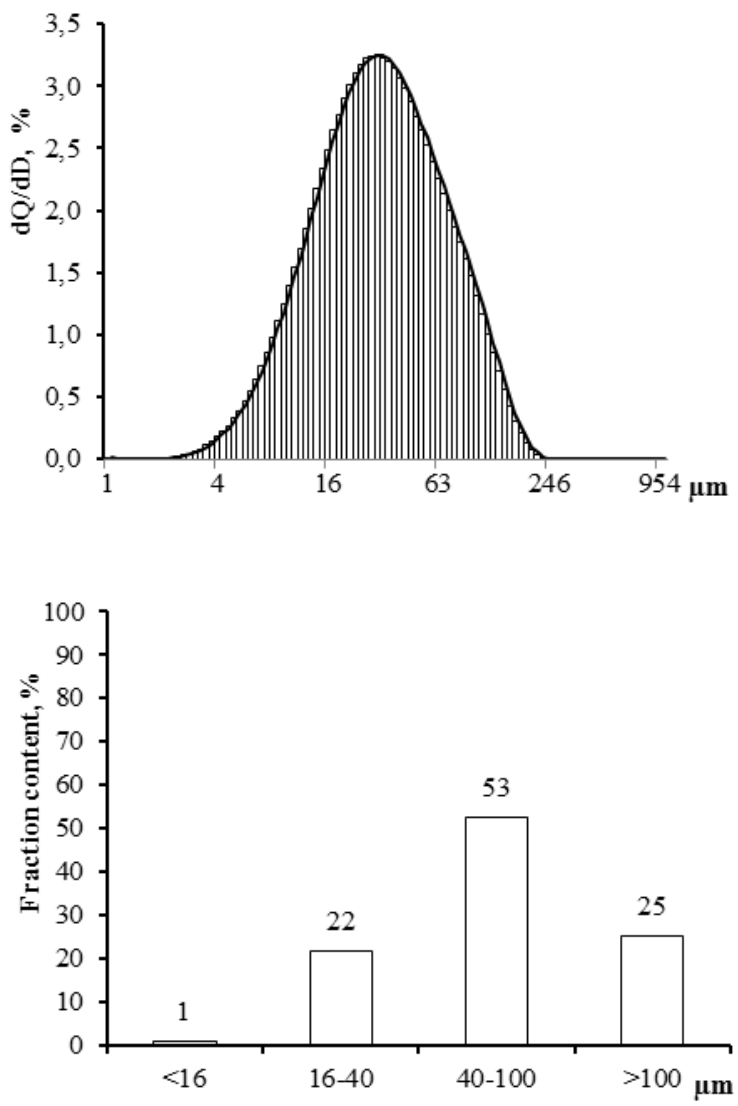

Fig. 2. Coagulate's granulometric composition

Coagulates elemental composition is shown in Table 2. The derived coagulate is composed primarily of carbon $(27.9 \%)$, oxygen $(49.4 \%)$. The aluminum, the metallic element that arised from the agent used for coagulation and sedimentation of the sludge, dominated among the inorganic elements of sludge.

TABLE I

COAGULATE ELEMENTAL COMPOSITION

\begin{tabular}{l|l|l|l|l|l|l}
\hline $\mathrm{C}, \%$ & $\mathrm{O}, \%$ & $\mathrm{H}, \%$ & $\mathrm{~N}, \%$ & $\mathrm{Al}, \%$ & $\mathrm{Na}, \%$ & $\mathrm{Cl}, \%$ \\
\hline \hline 27.9 & 49.4 & 4.3 & 0.3 & 10.9 & 4.1 & 3.1 \\
\hline
\end{tabular}

Carbon, oxygen and hydrogen are referred to organic components of coagulate, namely, to the pollutants of wood origin the deposition of which is of aluminumcontaining coagulant. The deposited pollutants of wood origin are characterized by a high content of hemicellulose $(75-80 \%)$. 
The structural characteristics of coagulates were studied by means of FT-IR and ${ }^{13} \mathrm{C}-\mathrm{NMR}$ methods.

The FT-IR of coagulate are illustrated in Fig. 3.

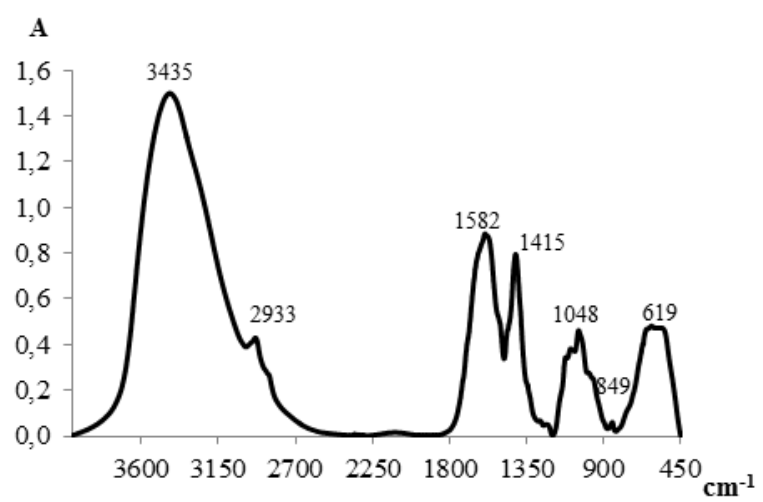

Fig. 3. FT-IR spectra of HLES-Al coagulate

A strong broad band at $3435 \mathrm{~cm}^{-1}$ was due to the stretching of hydroxyl groups, and the behaviour of these spectra in the $2934 \mathrm{~cm}^{-1}$ region shows the $\mathrm{C}-\mathrm{H}$ stretch in methyl and methylene groups. Intensive peak at $1567 \mathrm{~cm}$ ${ }^{1}$ characterise COO- skeletal vibrations in glucuronic acid. The wave number characteristic for typical xylan is 1046 $\mathrm{cm}^{-1}$ [14]. The adsorption at $1414 \mathrm{~cm}^{-1}$ are originated from aromatic skeletal vibrations in associated lignin [15].The absorbance at $849 \mathrm{~cm}^{-1}$ was attributed to $\beta$ glycosidic linkages between the sugars units. According to the coagulum FT-IR spectra the aluminum interaction with HLES occurs with HLES - Al coordination sites formation. Coordination takes place through HLES-OH and $-\mathrm{COOH}$ groups evidenced by the absorption band 619 $\mathrm{cm}^{-1}$ in the region characteristic of Al-O-link [16].

The ${ }^{13} \mathrm{C}-\mathrm{NMR}$ spectra of coagulate are illustrated in Fig. 4.

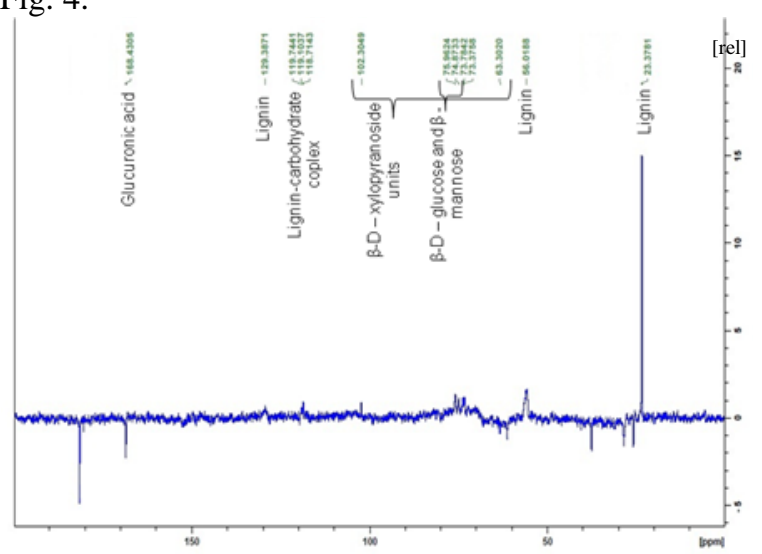

Fig. $4 .{ }^{13} \mathrm{C}-\mathrm{NMR}$ spectra of HLES-Al coagulate

The signal at $23.3 \mathrm{ppm}$ is most likely due to $-\mathrm{CH}_{3}$ from acetyl groups in hemicelluloses and lignin [17]. The shift at $56.02 \mathrm{ppm}$ is attributed to the presence of methoxyl groups of the aromatic rings of guaiacyl and syringyl units in lignin and methoxyl group of a 4-O-methyl-Dglucuronic acid residue in the xylan [18]. The peaks at $102.3,75.9,73.7,73.3$ and $63.3 \mathrm{ppm}$, which are attributed to $\mathrm{C}-1, \mathrm{C}-4, \mathrm{C}-3, \mathrm{C}-2$ and $\mathrm{C}-5$ of $\beta-\mathrm{D}-x y$ lopyranoside, respectively, confirmed the (1-4)- $\beta$-D-xylopyranoside linkage. The signals at 74.9 corresponds to $\mathrm{C}-3$ of $\alpha-\mathrm{L}$ - arabinofuranosyl residues linked to $\beta$-D-xylans [17]. However the signals at 74.9-75.9 ppm may be assigned to $\mathrm{C}-3$ in $\beta$-glucose and C-5 in $\beta$-mannose [19]. The peaks at 118.7-119.7 ppm can be attributed to the presence of an ester bond between the carboxyl group of D-glucuronic acid and phenylpropan side chains of lignin. The signal at 129.4 ppm may be assigned to carbon atoms in the phydroxyphenyl units [15]. The chemical shifts at 168.4 ppm represents the C-6 of glucuronic acid residues [19]. The presence of quantities of associated lignin was identified by one weak signal at $182.0 \mathrm{ppm}$, which originates from the carbonyl group in associated lignin [20].

This finding demonstrated that involved in the Alcoagulate are composed, mainly, of O-acetil-4-O-metil-Dglucuron- $\beta$-D-xylan with the presence of small amounts of $\beta-(1-4)$ linked glucomannose.

The derived HLES Al-coagulate may be considered as material, causing scientific and practical interest. Taking into account that the given coagulate is a waste of many tons, the question of its disposal or recycling is very topical.

\section{CONCLUSION}

Using the aluminium-containing composition coagulant based on polyaluminium chloride, coagulate is characterized by a low sludge volume index $\left(89 \mathrm{ml} \mathrm{g}^{-1}\right)$. The optimal time of sedimentation is $20-30$ minutes. The coagulate particles have an average size of $45.8 \mu \mathrm{m}$. The deposited pollutants of wood origin are characterized by a high content of hemicellulose $(75-80 \%)$. It is concluded that the hemicelluloses in the HLES-Al coagulate are characterized by O-acetyl-4-O-methyl-D-glucuron- $\beta$-Dxylan and with $\beta$-(1-4)-glucomannose. The derived coagulate is composed primarily of carbon (27.9\%), oxygen $(49.4 \%)$ and aluminum $(10.9 \%)$. Taking into account non-toxicity of hemicelluloses and the low aluminum content, the coagulate obtained is not seen as an intended one for disposal waste, but as a by-product, that can be used successfully in various industries.

\section{$\mathrm{V}$ ACKNOWLEDGEMENT}

The researches leading to these results have received funding from the Latvian Council of Science for a grant $\mathrm{n}^{\mathrm{o}}$ 09-1610c, as well as from the European Social Fund within the project ,Support for the implementation of doctoral studies at Riga Technical University.

\section{REFERENCES}

[1] G. Thompson, J. Swain, M. Kay, C.F. Forster, „The treatment of pulp and paper mill effluent: a review", Bioresource Technol., vol. 77, no 3, pp. 275-286, 2001.

[2] B.S.A. Murthy, T.A. Sihorwala, H.V. Tilwankar, D.J. Killedar, „Removal of colour from pulp and paper mill effluents by sorption technique - a case study", Indian J. Environ. Prot., vol. 11, no 5, pp. 360-370, 1991.

[3] Stephenson R.J., Duff S.J.B. Coagulation and precipitation of a mechanical pulping effluent-I. Removal of carbon, colour and turbidity. Water Res., 1996, Vol.30, pp. 781-792 
[4] M.H. Al-Malack, N.S. Abuzaid, A.H. El-Mubarak, „Coagulation of polymeric wastewater discharged by a chemical factory", Water Res., vol. 33, pp. 521-529, 1999.

[5] N.Z. Al-Mutairi, M.F. Hamoda, I. Al-Ghusain, „Coagulant selection and sludge conditioning in a slaughterhouse wastewater treatment plant", Bioresource Technol., vol. 95, pp. 115-119, 2004.

[6] W.S. Chen, F.C. Chang, Y.H. Shen, M.S. Tsai, „The characteristics of organic sludge/sawdust derived fuel", Bioresource Technol., vol. 102, pp. 5406-5410, 2011.

[7] Lakhdar, R. Scelza, R. Scotti, "The effect of compost and sewage sludge on soil biologic activities in salt affected soil", R.C. Suelo Nutr. Veg., vol. 10, no 1, pp. 40-47, 2010.

[8] D. Lin, C. Weng, "Use of sewage sludge ash as brick material", J. Environ. Eng., vol. 127, no 10, pp. 922-928, 2001.

[9] S. Rio, L. Le Coq, C. Faur, P. Le Cloirec, "Production of porous carbonaceous adsorbent from physical activation of sewage sludge: application to wastewater treatment", Water Sci. Technol., vol. 53, no 3, pp. 234-244, 2006

[10] M. Ahmaruzzaman, „Industrial wastes as low-cost potentia adsorbents for the treatment of wastewater laden with heavy metals" Advances in Colloid and Interface Science, vol. 166, pp. 36-59, 2011.

[11]J. Brovkina, G. Shulga, J. Ozolins, "Recovery of lignin and extractive substances from the hydrolysate of model birch wood hydrolysis with aluminium salt", Chemical Technol., Vol. 3-4, no 56, pp. 30-34, 2010.

[12] G. Shulga, S. Vitolina, J. Brovkina, B. Neiberte, A. Verovkins, M. Puke, N. Vedernikovs, "Wood biomass from the model wastewater and its fractionation", Proceedings of the $8^{\text {th }}$
International Scientific and Practical Conference Environment. Technology. Resources, Rezekne, Latvia, June 20-22, 2013.

[13] G. Šuļga, J. Brovkina, B. Neiberte., J. Ozoliņš, R. Neilands, "Koksnes pārstrādes uzṇēmumu notekūdeņu attīīǐšanas paņēmiens no lignīna un hemicelulozes vielām" LV Patenta pieteikums P-12-115 (04.07.2012.). Pieteikuma publicēšana notiks saskaņā ar Patenta likuma 35. panta 1. daļu 20.01.2014.

[14] X.F. Sun, Z. Jing, P. Fowler, Y. Wu, M. Rajaratnam, „Structural characterization and isolation of lignin and hemicelluloses from barley straw", Ind. Crop. Prod., vol. 33, pp. 588-598, 2011.

[15]T.Q. Yuan, S. Sun, F. Xu, R.C. Sun, "Isolation and physicochemical characterization of lignins from ultrasound irradiated fast-growing poplar wood", BioResources, vol. 6, no 1, pp. 414433, 2011.

[16]C.A. Contreras, S. Sugita, E. Ramos, „Preparation of sodium aluminate from basic aluminium sulphate", J. Mater. Online., vol. 2, 2006. [Online]. Available: http://www.azom.com

[17] J. Bian, F. Peng, F. Xu, R.C. Sun, J.F. Kennedy, „Fractional isolation and structural characterization of hemicelluloses from Caragana korshinskii”, Carbohyd. Polym., vol. 80, pp. 753-760, 2010.

[18]R.C. Sun, X.F. Sun, X.H. Ma, "Effect of ultrasound on the structural and physiochemical properties of organosolve soluble hemicelluloses from wheat straw", Ultrason. Sonochem., vol. 9, pp. 95-101, 2002.

[19]T. Heinze, T. Liebert, A. Koschella Esterification of polysaccharides. Springer-Verlag Berlin Heidelberg, Berlin, 2006.

[20] J.L. Ren, F. Peng, R.C. Sun, X.L. Zhang, "Preparation and characterization of carbamoylethyl hemicelluloses", e-Polymers, vol. 3, pp.1-11, 2009 